Editorial

\title{
Fossil Echinoderm Studies in China and other countries: historical and new perspectives
}

This special volume of Palaeoworld showcases current studies of stemmed echinoderms from China and other countries. Despite the large number of paleontologists in China, few Chinese scientists specialize in the study of stemmed echinoderms. Museum collections of Chinese echinoderms are rare. Historically reports of Chinese echinoderms have been relatively rare and surely underestimate actual biodiversity. We hope this collection of fifteen papers will serve as a catalyst for the discovery and analysis of additional faunas of stemmed echinoderms from China and adjacent areas in Asia.

China is a mosaic of numerous continental blocks as well as smaller continental fragments and accretionary complexes that have coalesced since the mid-Paleozoic. China contains the geologic history of the convergence between terranes having origins to the north of Paleo-Tethys with those terranes that rifted away from Gondwana during the middle Paleozoic. Echinoderm fossils from this diverse collage generally occur in areas of platform and shelf sedimentation on the margins of larger continental blocks such as North China, South China, and Sibumasu. However, echinoderms also have been collected from sedimentary accretionary wedge facies on active plate margins. Because Chinese terranes were situated on both the northern and southern margins of Paleo-Tethys, they have complex temporal, spatial, and climatic relationships. Many echinoderms tend to be highly endemic, thus their geographic distribution within faunas can play extremely important roles in delineating paleogeographic positions of these terranes through time.

Although individual taxa were figured earlier (Lin and Fürsich, 2015; Stiller and Lin, 2015), Tien (1926) published one of the earliest reviews of echinoderms known from Asia. Tien (1926) and Tien and Mu (1955) also listed known echinoderm occurrences from China and compared these echinoderms with other known faunas. Later papers on Chinese echinoderm occurrences are listed in Bassler and Moody (1943) and Webster (1973, 1977, 1986, 1988, 2003), which provide taxonomic compilations of echinoderms with brief notes on geographic occurrences. Recent, more comprehensive studies of Paleozoic echinoderm communities from China include Chen and Yao (1993), Lane et al. (1997), Waters et al. (2003a, 2003b), and Webster et al. (2010).

Echinoderm studies in this volume span the Phanerozoic, but the majority concentrates on aspects of Paleozoic taxa. Spectacularly preserved Cambrian echinoderm faunas from China 
are the topic of five papers. Some are taxonomic (Yang et al., 2015) and others concentrate on morphology (Lin et al., 2015; MacLeod, 2015) or paleoecology (Parsley, 2015). Mao et al. (2015) discuss the highly unusual morphology of the Petalocrinidae and the fact that China was the center of origination for this most unusual family of crinoids. One paper expands the paleogeographic reach of the Cambrian echinoderm fauna to the North China Plate (Ng et al., 2015). Other papers revise the taxonomy of Paleozoic echinoderm genera based on new studies of Chinese crinoids (Sheffield, 2015; Webster and Chen, 2015) or expand our knowledge of Carboniferous crinoid biogeography (Mirantsev, 2015). The beautifully preserved and globally famous Traumatocrinus beds in Southwest China are the subject of two papers in the volume. Lin (2015) discusses the history of the discovery of the Traumatocrinus beds while Hagdorn and Wang (2015) discuss the crinoid's morphology, ontogeny, and taphonomy. Finally Webster and Donovan (2015) review the species of Graphiocrinus from West Timor and Oji (2015) summarizes regeneration, predatory-prey interaction, and evolutionary history of articulate crinoids.

Proposal of this special issue was initiated during JPL's research visit to WIA in the summer of 2013. Lin's (2015) review on a pre-1950 collection of figured material of Traumatocrinus from China received positive feedback and attracted more colleagues to submit papers to this special issue. As co-editor-in-chief of Palaeoworld Dr. Norman MacLeod (2015) contributed a pilot study on gogiid form variations using landmark analyses. Young scientists from Russia (Mirantsev, 2015) and USA (Sheffield, 2015) contributed taxonomic papers. Many thanks to Dr. Tatsuo Oji and Dr. Frank Stiller for their trust and friendship developed from this project. We would like to express our thanks to the Academician Jia-Yu Rong and Nanjing Institute of Geology and Palaeontology, Chinese Academy of Sciences (NIGPAS) director Qun Yang who gave continuously positive feedback and encouragement for this special issue. As the first Chinese journal issue devoted to fossil echinoderms, we hope this is the beginning of new generations of workers who will devoted their time to study the Echinodermata through the lens of fossil material from China and other countries.

This project cannot be completed without the funding supports from the Chinese Academy of Sciences (KZCX2-YW-BR-23); the National Natural Science Foundation of China (41372022); State Key Laboratory of Palaeobiology and Stratigraphy (20131103); Taiwan Ministry of Science and Technology (104-2116-M-002-001); National Taiwan University (104R3231); National Science Foundation (DEB 1036416).

\section{References}


Bassler, R.S., Moody, M.W., 1943. Bibliographic and faunal index of Paleozoic Pelmatozoan echinoderms. Geological Society of America, Special Paper 45, 732 pp.

Chen, Z.T., Yao, J.H., 1993. Palaeozoic Echinoderm Fossils of Western Yunnan, China. Geological Publishing House, Beijing, 102 pp. (in Chinese).

Hagdorn, H., Wang, X.F., 2015. The pseudoplanktonic crinoid Traumatocrinus from the Late Triassic of Southwest China - morphology, ontogeny, and taphonomy. Palaeoworld, this issue.

Lane, N.G., Waters, J.A., Maples, C.G., 1997. Echinoderm faunas of the Hongguleleng Formation, Late Devonian (Famennian), Xinjiang-Uygur Autonomous Region, China. Paleontological Society Memoir 47, 1-43.

Lin, J.P., 2015. Treasure with blood: on the discovery of Traumatocrinus (Echinodermata, Triassic) crowns in China. Palaeoworld, this issue.

Lin, J.P., Fürsich, F.T., 2015. The oldest illustration of Chinese crinoid calyx: annotated translation of "Cupressocrinus abbreviatus" reported by Fritz Frech in 1911. Palaeoworld, this issue.

Lin, J.P., Ausich, W.I., Zhao, Y.L., Peng, J., Tai, T.S., 2015. Crypto-helical body plan in partially disarticulated gogiids from the Cambrian of South China. Palaeoworld, this issue.

MacLeod, N., 2015. Use of landmark and outline morphometrics to investigate thecal form variation in crushed gogiid echinoderms. Palaeoworld, this issue.

Mao, Y.Y., Lin, J.P., Lin, C.H., Ausich, W.I., 2015. Chinese origin and radiation of the Palaeozoic Crinoid Family Petalocrinidae. Palaeoworld, this issue.

Mirantsev, G.V., 2015. New data on the distribution of the Upper Carboniferous (Pennsylvanian) flexible crinoid Cibolocrinus (Crinoidea, Flexibilia). Palaeoworld, this issue.

Ng, T.W., Botting, J.P., Lin, J.P., 2015. New discoveries of Cambrian pelmatozoan echinoderm ossicles from North China. Palaeoworld, this issue.

Oji, T., 2015. Regeneration, predatory-prey interaction, and evolutionary history of articulate crinoids. Palaeoworld, this issue.

Parsley, R., 2015. Flume studies using 1:1 scale models of Series 2 and basal Series 3 Cambrian gogiid eocrinoids from Guizhou Province, China to determine feeding posture and mode of attachment. Palaeoworld, this issue.

Sheffield, S.L., 2015. A brief history and revision of the systematics of the cladid crinoid Sinocrinus. Palaeoworld, this issue. 
Stiller, F., Lin, J.P., 2015. The earliest scientific descriptions of Chinese fossil echinoderms in a late nineteenth-century publication by Lajos Lóczy (Ludwig von Lóczy). Palaeoworld, this issue.

Tien, C.C., 1926. Crinoids from the Taiyuan Series of north China. Palaentologica Sinica 5, 1-58. Tien, C.C., Mu, A.T., 1955. Echinodermata. In: Sun, Y.Z. (Ed.), Index Fossils of China, Invertebrate Volume 1. Geological Publishing House, Beijing, pp. 83-95 (in Chinese).

Waters, J.A., Lane, N.G., Maples, C.G., Marcus, S.A., Liao, Z.T., Liu, L., 2003a. A Quadrupling of Famennian Pelmatozoan Diversity: New Late Devonian Blastoids and Crinoids from the Late Devonian (Famennian) of Northwest China. Journal of Paleontology 77 (5), $922-$ 948.

Waters, J.A., Liao, Z.T., Liu, L., Lane, N.G., Maples, C.G., Marcus, S.A., 2003b. Redescription of Devonian and Carboniferous Blastoids from western Yunnan, China. Journal of Paleontology 77 (6), 933-936.

Webster, G.D., 1973. Bibliography and index of Paleozoic crinoids, 1942-1968. Geological Society of America, Memoir 137, 1-341.

Webster, G.D., 1977. Bibliography and index of Paleozoic crinoids, 1969-1973. Geological Society of America, Microform Publication 8, 1-235.

Webster, G.D., 1986. Bibliography and index of Paleozoic crinoids, 1974-1980. Geological Society of America, Microform Publication 16, 1-405.

Webster, G.D., 1988. Bibliography and index of Paleozoic crinoids, 1981-1985. Geological Society of America, Microform Publication 18, 1-235.

Webster, G.D., 2003. Bibliography and index of Paleozoic crinoids, coronates, and hemistreptocrinoids 1758-1999. Geological Society of America, Special Paper 363, 2335 pp., http://crioid.gsajournals.org/crinoidmod/ (now off line).

Webster, G.D., Chen, X.Q., 2015. Lower Middle Devonian, Eifelian, crinoids from central Guangxi, South China. Palaeoworld, this issue.

Webster, G.D., Donovan, S.K., 2015. Review and revision of the West Timor Permian Graphiocrinus species of Johannes Wanner. Palaeoworld, this issue.

Webster, G.D., Waters, J.A., Chen, X.Q., 2010. Revision of the Chen and Yao Devonian to Permian crinoids from Western Yunnan. Palaeobiodiversity and Palaeoenvironments 89, 119-160.

Yang, Z.C., Lin, J.P., Zhang, Y.P., Wu, Y.S., Meng, X.Y., 2015. A new eocrinoid fauna (Cambrian Series 2) from Guizhou Province, South China. Palaeoworld, this issue. 
(Alex) Jih-Pai Lin

Department of Geosciences, National Taiwan University, P.O. Box 13-318, Taipei 106, Taiwan, China William I. Ausich School of Earth Sciences, Ohio State University, Columbus, OH 43210, USA Johnny Waters Department of Geology, Appalachian State University, 572 Rivers Street, Boone, NC 28608, USA

E-mail addresses: alexjplin@ntu.edu.tw (J.P. Lin), ausich.1@osu.edu (W.I. Ausich), watersja@appstate.edu (J. Waters) 